Tersedia online di: http://ejournal-balitbang.kkp.go.id/index.php/jra

\title{
ISOLASI DAN KARAKTERISASI BAKTERI NITRIFIKASI DAN DENITRIFIKASI SEBAGAI KANDIDAT PROBIOTIK
}

\author{
Yosmaniar\#, Hessy Novita, dan Eri Setiadi \\ Balai Riset Perikanan Budidaya Air Tawar dan Penyuluhan Perikanan \\ (Naskah diterima: 5 Desember 2017; Revisi final: 10 Januari 2018; Disetujui publikasi: 10 Januari 2018)
}

\begin{abstract}
ABSTRAK
Senyawa nitrogen yang tinggi pada limbah budidaya perikanan intensif dapat memperburuk kualitas air, sehingga perlu diatasi dengan penambahan probiotik untuk proses bioremediasi. Tujuan penelitian ini adalah untuk mendapatkan bakteri nitrifikasi dan denitrifikasi yang berpotensi sebagai kandidat probiotik pengendali senyawa nitrogen pada budidaya ikan air tawar. Tahap penelitian terdiri atas: 1) koleksi sampel air dan sedimen dari kolam budidaya ikan patin di kawasan minapolitan Desa Pudak Kecamatan Kumpeh Kabupaten Muaro Jambi Provinsi Jambi dan Desa Koto Mesjid Kecamatan XIII Koto Kampar Kabupaten Kampar Provinsi Riau; 2) pengujian sampel secara in vitro yang meliputi: a) Isolasi dan seleksi bakteri nitrifikasi dan denitrifikasi; b) Karakterisasi morfologis bakteri terpilih; c) Karakterisasi fisiologi/biokimia isolat bakteri terpilih; d) Karakterisasi genetika isolat bakteri terpilih dengan sekuensing 16S-rRNA. Analisis data dilakukan secara deskriptif. Berdasarkan hasil penelitian diperoleh empat isolat bakteri nitrifikasi dan empat isolate bakteri denitrifikasi. Isolat bakteri nitrifikasi Pandoraea pnomenusa strain 1318 (NP1); Pseudomonas aeruginosa strain PSE12 (NP2); Pseudomonas aeruginosa strain PSE12 (NP3); Burkholderia vietnamiensis strain NE 7 (NP4); dan denitrifikasi Achromobacter xylosoxidans strain TPL14 (DP1); Stenotrophomonas acidaminiphila strain BTY (DP2); Stenotrophomonas maltophilia strain BHWSL2 (DP3); Ochrobactrum intermedium strain: SQ 20 (DP4) Achromobacter xylosoxidans strain TPL14 (DP1); Stenotrophomonas acidaminiphila strain BTY (DP2); Stenotrophomonas maltophilia strain BHWSL2 (DP3); Ochrobactrum intermedium strain: SQ 20 (DP4); yang berpotensi digunakan sebagai kandidat probiotik pengendali senyawa nitrogen pada budidaya ikan air tawar.
\end{abstract}

KATA KUNCl: bakteri nitrifikasi; bakteri denitrifikasi; karakterisasi; probiotik

ABSTRACT: Isolation and characterization of nitrifying and denitrifying bacteria as probiotic candidates. By: Yosmaniar, Hessy Novita, and Eri Setiadi

Wastes from an intensive aquaculture contain nitrogen compounds which, if untreated, could rapidly reduce water quality condition within the system. The addition of probiotics as bioremediation to aquaculture system has been used to improve water quality with promising results. The aim of this study was to obtain potential nitrifying and denitrifying bacteria that could be used as probiotic candidates to control excessive nitrogen compounds in freshwater culture. This study consisted of two steps, 1) the collection of water samples and sediments from catfish ponds at 'M inapolitan Area" in Pudak Village, Jambi Province and Koto M esjid Village, Riau Province; 2) in vitro tests consisting of isolation and selection of nitrifying and denitrifying bacteria; morphological characterization of the selected nitrifying and denitrifying bacteria; characterization of physiological/biochemical selected nitrifying and denitrifying bacteria; genetic characterization of the selected nitrifying and denitrifying bacteria with 16SrRNA sequencing. All data were analyzed descriptively. The study had found four nitrifying bacteria isolates: Pandoraea pnomenusa strain 1318 (NP1); Pseudomonas aeruginosa strain PSE 12 (NP2); Pseudomonas aeruginosa strain PSE12 (NP3); Burkholderia vietnamiensis strain NE 7 (NP4). The study also found four isolates of denitrifying bacteria isolates: Achromobacter xylosoxidans strain TPL14 (DP1); Stenotrophomonas acidaminiphila strain BTY (DP2); Stenotrophomonas maltophilia strain BHWSL2 (DP3); Ochrobactrum intermedium strain: SQ 20 (DP4). All the identified nitrifying and denitrifying bacteria isolates have the potential to be used as probiotic candidates to control nitrogen compound in freshwater aquaculture.

KEYWORDS: nitrifying bacteria; denitrifying bacteria; characterization; probiotic

\footnotetext{
\# Korespondensi: Balai Riset Perikanan Budidaya Air Tawar dan Penyuluhan Perikanan. Jl. Sempur No. 1, Bogor 16154,

Indonesia. Tel. + 622518313200

E-mail: yosmaniar@yahoo.com
} 


\section{PENDAHULUAN}

Budidaya ikan secara intensif dengan padat penebaran dan jumlah pakan tinggi, dapat menyebabkan penumpukan bahan organik dan an organik yang berasal dari sisa pakan dan ekskresi metabolisme ikan dalam wadah budidaya (Djokosetiyanto et al., 2006) dan mengendap di dasar kolam. Hal ini berdampak pada penurunan kualitas air budidaya karena meningkatnya senyawa nitrogen (amonia, nitrit, dan nitrat) sehingga mengganggu keseimbangan siklus nitrogen seperti nitrifikasi dan denitrifikasi yang dapat menyebabkan keracunan dan mortalitas ikan.

Untuk memperbaiki kualitas air dapat dilakukan dengan memanfaatkan mikroorganisme (bioremediasi). Bioremediasi merupakan upaya untuk memperbaiki kualitas air melalui aktivitas biologi oleh mikroorganisme (Rusmana, 2003). Beberapa persyaratan bioremediasi, antaran lain mampu mengo ptimalkan laju nitrifikasi untuk menjaga amonia agar tetap rendah, mampu mengoptimalkan Iaju denitrifikasi untuk mengeliminir kelebihan nitrogen sebagai gas nitrogen dari kolam (Badjoeri \& Widiyanto, 2008; Khasani, 2008).

Agen bioremediasi yang digunakan memiliki kemampuan metabolisme nitrifikasi dan denitrifikasi, sehingga secara langsung dapat merombak bahan organik di dalam air media (Yuhana, 2010). Nitrifikasi merupakan reaksi penting dalam siklus nitrogen yang membutuhkan oksigen dalam proses oksidasi $\mathrm{NH}_{3}$, menjadi $\mathrm{NO}_{2}$ dan oksidasi $\mathrm{NO}_{2}$ menjadi $\mathrm{NO}_{3}$ (Agustiyani et al., 2010). Denitrifikasi merupakan proses mikrobial di mana $\mathrm{NO}_{3}$ dan $\mathrm{NO}_{2}$, diubah menjadi $\mathrm{NO}_{2}$ dan $\mathrm{N}_{2}$ di sedimen aerobik maupun anerobik (Long et al., 2013).

Isolasi, seleksi, dan karakterisasi merupakan tahapan penting untuk mendapatkan bakteri yang diharapkan sebagai kandidat untuk probiotik. Tahapan proses tersebut diperlukan agar jenis bakteri yang diperoleh memiliki kemampuan sesuai target. Pada tahap seleksi dibutuhkan medium bakteri yang tepat dan pengujian secara biokimia atau fisiologis. Tahap karakterisasi dilakukan untuk mengetahui jenis bakteri dan hubungan kekerabatannya menggunakan 16S rRNA sekuensing. Analisis Taksonomi menggunakan gen $16 \mathrm{~S}$ dan $18 \mathrm{~S}$ rRNA untuk mensekuensing data telah menunjukkan pendekatan yang valid dalam mengkarakterisasi komunitas bakteri (Sogin et al., 2006).

Penelitian ini bertujuan untuk mendapatkan bakteri nitrifikasi dan denitrifiksi yang berpotensi sebagai kandidat probiotik pengendali senyawa nitrogen pada budidaya ikanair tawar.

\section{BAHAN DAN METODE}

\section{Koleksi Sampel dari Sedimen dan Air}

Sampel air dan sedimen dikoleksi dari kolam budidaya ikan patin pada tahun 2013, di kawasan minapolitan Desa Pudak Kecamatan Kumpeh Kabupaten Muaro Jambi Provinsi Jambi dan Desa Koto Mesjid Kecamatan XIII Koto Kampar Kabupaten Kampar Provinsi Riau (Gambar 2). Kedua Desa tersebut merupakan sentra budidaya ikan patin intensif dan dijadikan sebagai kawasan minapolitan (Yantos, 2016). Pengambilan sampel air permukaan pada kolam ikan patin dilakukan di kedua desa dengan setiap desa sebanyak empat kolam. Kriteria kolam yang diambil sampel air dan sedimen merupakan kolam budidaya patin intensif. Untuk sampel air permukaan kolam ikan dilakukan lima titik per kolam, yaitu di setiap sudut kolam (empat sampel) dan di tengah kolam (satu sampel) menggunakan bobot sampel dengan volume $600 \mathrm{~mL}$ yang steril. Untuk sedimen, dilakukan tiga titik setiap kolam yaitu dua titik di dua sudut kolam dan satu titik di tengah kolam menggunakan eigment grab, kemudian sampel sedimen diambil sebanyak 300 g pada setiap titik. Selanjutnya sedimen dipindah ke dalam botol sampel steril. Botol sampel yang telah terisi air maupun sedimen dimasukkan ke dalam cool box.

\section{Isolasi dan Seleksi Bakteri Nitrifikasi dan Denitrifikasi}

Media spesifik untuk isolasi bakteri nitrifikasi dan denitrifikasi berdasarkan (Rodina, 1972), untuk 1000 $\mathrm{mL}$, yaitu: $13,5 \mathrm{~g} \mathrm{KH}_{2} \mathrm{PO}_{4} ; 0,7 \mathrm{~g} \mathrm{~K}_{2} \mathrm{HPO}_{4} ; 0,1 \mathrm{~g}$ $\mathrm{MgCl}_{2} \cdot 6 \mathrm{H}_{2} \mathrm{O} ; 0,18 \mathrm{~g} \mathrm{CaCl}_{2} 2 \mathrm{H}_{2} \mathrm{O} ; 0,1 \mathrm{~g} \mathrm{NH}_{4} \mathrm{Cl} ; 0,2 \mathrm{~g}$ EDTA dan $0,5 \mathrm{~g} \mathrm{Na}_{2} \mathrm{CO}_{3} ; 0,18 \mathrm{~g} \mathrm{FeCl}_{3} 6 \mathrm{H}_{2} \mathrm{O}$; dan 0,5 g glukosa. Sedangkan untuk bakteri denitrifikasi: $10 \mathrm{~g} \mathrm{Na}$-asetat, $5 \mathrm{~g} \mathrm{KNO}_{3} ; 0,2 \mathrm{~g} \mathrm{KH}_{2} \mathrm{PO}_{4} ; 0,9 \mathrm{~g} \mathrm{~K}_{2} \mathrm{HPO}_{4} ; 0,1 \mathrm{~g} \mathrm{CaCl} 2 \mathrm{H}_{2} \mathrm{O}$; $0,5 \mathrm{~g} \mathrm{MgSO}_{4} 7 \mathrm{H}_{2} \mathrm{O}$; dan $0,2 \mathrm{~g}$ EDTA.

Sebanyak $5 \mathrm{~mL}$ sampel air dan $1 \mathrm{~g}$ sedimen dimasukkan ke dalam media nitrifikasi cair pada erlenmeyer, kemudian diinkubasi selama 7 hari menggunakan shaker pada suhu $28^{\circ} \mathrm{C}$ dengan kecepatan $130 \mathrm{rpm}$, selanjutnya senyawa nitrat yang dihasilkan diukur menggunakan metode Brucine menggunakan Spectrofotometer (Clesceri et al., 1998).

Sebanyak $5 \mathrm{~mL}$ suspensi dari kultur bakteri yang positif menghasilkan nitrat diinokulasi ulang pada erlenmeyer media nitrifikasi kemudian diinkubasi selama 7 hari menggunakan shaker pada suhu $28^{\circ} \mathrm{C}$ dengan kecepatan 130 rpm. Sebanyak satu ose dari kultur bakteri digores pada media agar nitrifikasi dengan menggunakan metode kuadran (Sanders, 2012), kemudian diinkubasi dalam inkubator pada suhu $29^{\circ} \mathrm{C}$ 


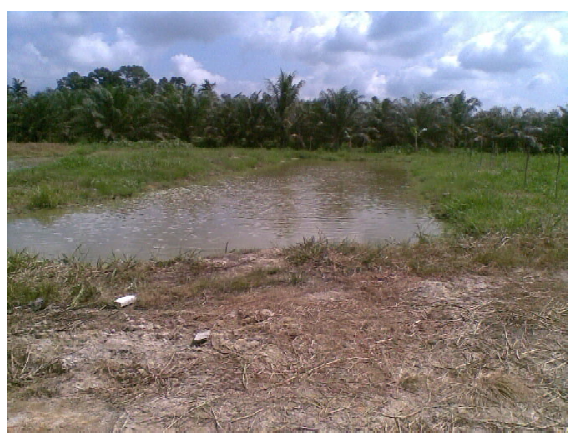

(A)

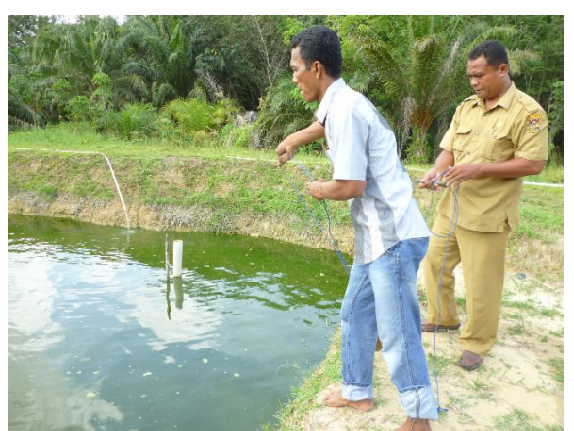

(B)

Gambar 1. Lokasi pengambilan sampel air dan sedimen di kawasan minapolitan Desa Pudak Kecamatan Kumpeh Kabupaten Muaro Jambi (A), Desa Koto Mesjid Kecamatan XIII Koto Kampar Kabupaten Kampar Provinsi Riau (B).

Figure 1. Locations of water and sediment sampling in the study sites: (A) Pudak Village, (B) Koto Mesjid Village.

selama 5-7 hari. Koloni yang terpisah dimurnikan kembali dengan cara menggores ulang pada media agar nitrifikasi. Isolat murni yang diperoleh digunakan untuk uji selanjutnya.

Sebanyak $1 \mathrm{~mL}$ sampel air dan $1 \mathrm{~g}$ sedimen dimasukkan ke dalam tabung ulir yang berisi $20 \mathrm{~mL}$ media denitrifikasi cair, kemudian diinkubasi pada suhu $28^{\circ} \mathrm{C}$ selama 7 hari. Perubahan tingkat kekeruhan dan gas yang dihasilkan pada tabung durham menunjukkan adanya bakteri denitrifikasi. Sebanyak 2 mLsuspensi kultur bakteri yang positif menghasilkan gas diinokulasi ulang dalam media denitrifikasi cair pada tabung reaksi volume $22 \mathrm{~mL}$ yangmengandung bakteri denitrifikasi, kemudian diinkubasi pada suhu $28^{\circ} \mathrm{C}$ selama 7 hari. Satu ose dari kultur bakteri digores pada media agar denitrifikasi dengan menggunakan metode kuadran dan diinkubasi pada kondisi anaerob dalam Anaerobik jar selama 7-10 hari. Koloni sel yang terpisah dimurnikan kembali dengan digores kuadran pada media cawan dan diinkubasi pada kondisi anaerobik. Isolat murni yang diperoleh selanjutnya dilakukan uji oksidatif/fermentatif.

\section{Karakterisasi, Morfologis, Biokimia Bakteri Nitrifikasi, dan Denitrifikasi}

Karakterisasi bakteri nitrifikasi dan denitrifikasi dilakukan dengan melakukan pengamatan secara morfologis pada bentuk dan warna koloni bakteri serta melalui pewarnaan gram. Setelah itu, isolat yang terseleksi kemudian diuji secara biokimia (Novita et al., 2014). Isolat yang terseleksi kemudian diuji secara biokimia dengan menggunakan kit API untuk melihat kemampuan bakteri dalam menggunakan gula-gula yang ada pada media sebagai sumer $\mathrm{C}$ dan $\mathrm{N}$. Ciri biokimia merupakan kriteria yang amat penting di dalam identifikasi spesimen bakteri yang tak dikenal karena secara morfologis biakan ataupun sel bakteri yang berbeda dapat tampak serupa, tanpa hasil pengamatan fisiologis yang memadai mengenai organik yang diperiksa maka penentuan spesiesnya tidak mungkin dilakukan. Karakteristik dan klasifikasi sebagai mikroba seperti bakteri berdasarkan pada reaksi enzimatik ataupun biokimia. Mikroba dapat tumbuh pada beberapa tipe media memproduksi metabolit tentunya yang dideteksi dengan interaksi mikroba dengan reagen test yang mana menghasilkan perubahan warna reagen (Murray et al., 2005).

\section{Karakterisasi Isolat Bakteri Nitrifikasi dan Denitrifikasi Terpilih dengan Sekuensing 16S- rRNA}

Karakterisasi bakteri nitrifikasi dan denitrifikasi yang terpilih secara molekuler dengan 16S rRNA sekuensing dilakukan untuk mengetahui jenis dan kekerabatan isolat bakteri. DNA isolat terpilih diekstraksi dengan metode geneaid kit (prosedur sesuai dengan instruksi manual dalam kit). Setelah itu dilakukan uji PCR menggunakan primer 16SrRNA (Marchesi et al., 1998) dengan susunan primer forward $63 f$ (52 -CAG GCC TAA CAC ATG CAA GTC-32), dan primer Reverese, 1387r (52 -GGG CGG WGT GTA CAA GGC-32 ). Amplifikasi PCR dilakukan sebanyak 30 siklus menggunakan suhu predenaturasi $95^{\circ} \mathrm{C}$ selama 5 menit, denaturasi pada suhu $92^{\circ} \mathrm{C}$ selama 30 detik, annealing pada suhu $55^{\circ} \mathrm{C}$ selama 30 detik, elongation $72^{\circ} \mathrm{C}$ selama 1 menit, dan final extention dengan suhu $72^{\circ} \mathrm{C}$ selama 5 menit.

\section{Sekuensing dan Dendogram}

Hasil PCR 16S rRNA menunjukkan target pita DNA berada pada $1300 \mathrm{bp}$. Isolat yang telah di PCR kemudian di sekuensing. Hasil sekuensing dari masing- 
masing isolat disejajarkan dengan sekuen dari Genebank selanjutnya dilakukan BLAST di NCBI untuk melihat tingkat kemiripannya dengan sekuen di Genebank.

Kemudian hasil sekuensing disejajarkan lagi dengan program MEGA 5 untuk mendapatkan dendogram

\section{Analisis Data}

Semua data yang diperoleh ditabulasi dengan bantuan Microsoft Excel 2010. Data yang diperoleh dari isolasi, seleksi, dan identifikasi bakteri kandidat probiotik dianalisis secara deskriptif dan ditampilkan dalam tabel.

\section{HASIL DAN BAHASAN}

\section{Isolasi Bakteri Nitrifikasi dan Denitrifikasi}

Hasil isolasi bakteri kandidat probiotik yang teridentifikasi. Kelompok denitrifikasi di Desa Pudak, Jambi lebih banyak dibandingkan nitrifikasi, sedangkan di Riau nitrifikasi lebih dominan dibandingkan denitrifikasi. Kondisi perbedaan tersebut mengindikasikan bahwa kedalaman kolam (kolom air) dan kandungan bahan organik baik di air maupun di sedimen diduga berpengaruh terhadap perbedaan jumlah bakteri nitrifikasi dan bakteri denitrifikasi. Azhar et al. (2017) melaporkan bahwa kelimpahan dan keanekaragaman bakteri dipengaruhi oleh kedalaman air, ketebalan sedimen, dan kandungan bahan organik baik di air maupun di sedimen.

Jumlah isolat yang berhasil diisolasi dari dua lokasi pengambilan contoh disajikan pada Tabel 1.

\section{Karakterisasi Isolat Bakteri Nitrifikasi dan Denitrifikasi}

Diperoleh 4 isolat bakteri nitrifikasi dan 4 isolat bakteri denitrifikasi dengan ciri morfologi koloni isolat tepian sama yaitu licin sedangkan warna, permukaan, dan bentuk umumnya hampir sama (Tabel 2). Bakteri nitrifikasi terpilih NP1 dan NP4 bersifat gram positif sedangkan NP2 dan NP3 merupakan gram negatif. Pada isolate bakteri nitrifikasi ditemukan ada yang gram negatif. Hal ini menunjukkan bahwa isolate NP2 dan NP3 dapat berperan ganda (nitrifikasi dan denitrifikasi). Semua bakteri denitrifikasi merupakan gram negatif. Empat isolat bakteri nitrifikasi yaitu NP1, NP2, NP3, NP4 termasuk ke dalam kelompok bakteri heterotrof.

Pertumbuhan bakteri heterotrof lebih baik dibandingkan dengan bakteri autrotof. Dengan demikian dapat dikatakan bahwa keempat isolat bakteri nitrifikasi termasuk ke dalam kelompok bakteri heterotrof. Bakteri ini merupakan bakteri yang tidak dapat memfiksasi karbon dan menggunakan karbon organik untuk pertumbuhannya (Tabel 3). Bakteri heterotrof terbagi menjadi dua kelompok berdasarkan pada penggunaan energi, yaitu: a) fotoheterotrof, yang menggunakan cahaya sebagai sumber energi, dan b) kemoheterotrof, yang menggunakan senyawa organik maupun anorganik sebagai sumber energi (Hogg \& Stuart, 2013). Pertumbuhan bakteri heterotrof lebih baik dibandingkan dengan bakteri autrotof. Hal ini sesuai dengan penelitian yang dilakukan oleh Michauda et al. (2006) yang melaporkan bahwa pertumbuhan bakteri heterotrof lebih cepat dibandingkan dengan bakteri autrotof.

Uji oksidatif-fermentatif dilakukan pada bakteri denitrifikasi dengan tujuan mencari isolat yang bersifat oksidatif dan fermentatif. Jika bakteri bersifat fermentatif akan terjadi perubahan warna dari yang hijau menjadi kuning, sedangkan bakteri yang bersifat oksidatif akan tetap bewarna hijau (Novita et al., 2014).

Isolat bakteri DP1 dan DP4 serta bakteri NP2 dan NP3 merupakan gram negatif. Bentuk sel semua isolat adalah basil. Keempat isolat bakteri nitrifikasi bersifat oksidatif. Umumnya bakteri denitrifikasi bersifat oksidatif, karena dalam proses metabolisme untuk tumbuh dan berkembang membutuhkan oksigen.

Tabel 1. Jumlah isolat bakteri nitrifikasi dan denitrifikasi yang diisolasi dari budidaya ikan patin di Jambi dan Riau

Table 1. Number of nitrifying and denitrifying isolates from catfish culture in Jambi and Riau

\begin{tabular}{lcccc}
\hline \multicolumn{1}{c}{$\begin{array}{c}\text { Asal sampel } \\
\text { Origin of sample }\end{array}$} & $\begin{array}{c}\text { Jenis sampel } \\
\text { Kind of sample }\end{array}$ & \multicolumn{2}{c}{ Jumlah isolat (Number of isolate) } \\
\cline { 3 - 5 } & $\begin{array}{c}\text { Bakteri nitrifikasi } \\
\text { Nitrification bacteria }\end{array}$ & $\begin{array}{c}\text { Bakteri denitrifikasi } \\
\text { Denitrification bacteria }\end{array}$ & $\begin{array}{c}\text { Total } \\
\text { Total }\end{array}$ \\
\hline Desa Pudak Kecamatan Kumpeh & Air (Water ) & 7 & 8 & 15 \\
Kabupaten M uaro Jambi Provinsi Jambi & Sedimen (Sediment) & 7 & 7 & 14 \\
Desa Koto M esjid Kecamatan XIII Koto Kampar & Air (Water ) & 9 & 9 & 18 \\
Kabupaten Kampar Provinsi Riau & Sedimen (Sediment) & 10 & 9 & 19 \\
\hline \multicolumn{1}{c}{ Total } & & $\mathbf{3 3}$ & $\mathbf{3 3}$ & $\mathbf{6 6}$ \\
\hline
\end{tabular}


Tabel 2. Morfologi dan karakteristikkoloni isolat bakteri nitrifikasi dan denitrifikasi yang terpilih Table 2. Morphology and characteristic of selected isolates of nitrifying and denitrifying bacteria

\begin{tabular}{|c|c|c|c|c|c|}
\hline \multirow{2}{*}{$\begin{array}{l}\text { Isolat } \\
\text { Isolate }\end{array}$} & \multicolumn{5}{|c|}{ Morfologi karakteristik koloni isolat (Morphology and characteristics of colonies) } \\
\hline & $\begin{array}{l}\text { Warna } \\
\text { Colour }\end{array}$ & $\begin{array}{l}\text { Tepian } \\
\text { Edge }\end{array}$ & $\begin{array}{l}\text { Permukaan } \\
\text { Surface }\end{array}$ & $\begin{array}{l}\text { Bentuk sel } \\
\text { Shape of cell }\end{array}$ & $\begin{array}{l}\text { Reaksi gram } \\
\text { Gram reaction }\end{array}$ \\
\hline \multicolumn{6}{|c|}{ Nitrifikasi (Nitrification) } \\
\hline NP1 & Putih (White) & Licin (Slippery) & Datar (Flat) & Basil & Positif (Positive) \\
\hline NP2 & Putih (White) & Licin (Slippery) & Cembung (Convex) & Basil & Negatif (Negative) \\
\hline NP3 & Kecoklatan (Brownish) & Licin (Slippery) & Cembung (Convex) & Basil & Negatif (Negative) \\
\hline NP4 & Kecoklatan (Brownish) & Licin (Slippery) & & Basil & Positif (Positive) \\
\hline \multicolumn{6}{|c|}{ Denitrifikasi (Denitrification) } \\
\hline DP1 & Kecoklatan (Brownish) & Licin (Slippery) & & Basil & Negatif (Negative) \\
\hline DP2 & Putih pucat (Pale white) & Licin (Slippery) & Timbul (Arise) & Kokus (Coccus) & Negatif (Negative) \\
\hline DP3 & Kekuningan (Yellowish ) & Licin (Slippery) & Cembung (Convex) & Basil & Negatif (Negative) \\
\hline DP4 & Kekuningan (Yellowish ) & Licin (Slippery) & Datar (Flat) & Basil & Negatif (Negative) \\
\hline
\end{tabular}

Tabel 3. Pertumbuhan isolat bakteri nitrifikasi yang terpilih

Table 3. Growth of selected nitrifying bacteria isolates

\begin{tabular}{ccc}
\hline \multirow{2}{*}{$\begin{array}{c}\text { Isolat } \\
\text { Isolate }\end{array}$} & \multicolumn{2}{c}{$\begin{array}{c}\text { Pertumbuhan isolat bakteri nitrifikasi } \\
\text { Growth of nitrifying bacteria isolates }\end{array}$} \\
\cline { 2 - 3 } & $\begin{array}{c}\text { Heterotrof } \\
\text { Heterotroph }\end{array}$ & $\begin{array}{c}\text { Autotrof } \\
\text { Autotroph }\end{array}$ \\
\hline NP1 & ++++ & + \\
NP2 & ++++ & + \\
NP3 & ++++ & + \\
NP4 & ++++ & + \\
\hline
\end{tabular}

Keterangan (Note): $++++=$ pertumbuhan sangat cepat (very rapid growth)

$+=$ pertumbuhan sangat lambat (very slow growth)

\section{Karakterisasi Biokimia Isolat Bakteri Nitrifikasi dan Denitrifikasi}

Dari hasil Table 4 di atas menunjukkan bahwa bakteri nitrifikasi dan denitrifikasi terpilih (NP2 dan NP4) dan (DP1 dan DP3) dapat memanfaatkan bahan uji biokimia dengan baik sebagai media tumbuh sehingga berotensi sebagai kandidat.

\section{Karakterisasi Isolat Bakteri Nitrifikasi dan Denitrifikasi Terpilih dengan Sekuensing 16S- rRNA}

Hasil karakterisasi berdasarkan 16SrRNA dapat dilihat pada Gambar 3. Hasil PCR dengan 16S rRNA menunjukkan bahwa isolat terpilih menghasilkan pita PCR pada target 1300 bp. Hasil sekuensing yang dilakukan dengan membandingkan sekuen yang ada di Genebank diperoleh hasil BLAST N seperti disajikan pada Tabel 5.

Dendogram filogeni dari isolat bakteri nitrifikasi dan denitrifikasi, disajikan pada Gambar 3 dan 4. Isolat
DP1 menunjukkan kemiripan 100\% dengan Achromobacter xylosoxidans strain TPL14. Isolat DP2 dan DP3 homolog dengan Stenotrophomonas acidaminiphila strain BTY dan Stenotrophomonas maltophiliastrain BHWSL2 dengan tingkat kemiripan 100\%dan 99\% Sedangkan untuk isolat NP1 homolog dengan Pandoraea pnomenusa strain 1318 dengan tingkat kemiripan 99\% begitu juga dengan NP2, NP3 homolog dengan Pseudomonas aeruginosa strain PSE12 dengan kemiripan $99 \%$ sedangkan isolat NP4 homolog 98\%dengan Burkholderia vietnamiensis strain NE 7.

Hasil sekuensing isolat bakteri nitrifikasi NP1 menunjukkan bahwa bakteri isolat NP1 memiliki kekerabatan terdekat dengan genus Pandoraea dan Burkholderia. Namun paling dekat dengan jenis Pandoraea pnomenusa strain 1318. Jenis bakteri genus Pandoraea yang pertama kali terbukti memiliki kemampuan dalam mendegradasi dichlorometan adalah Pandoraea pnomenusa LX-1 (Fu et al., 2012). Bakteri Pandoraea pnomenusa memiliki kemampuan dalam memanfaatkan sumber karbon sebagai energi 
Tabel 4. Karakteristik biokimia isolat bakteri nitrifikasi dan denitrifikasi

Table 4. Biochemistry characteristics of the nitrifying and denitrifying bacteria

\begin{tabular}{|c|c|c|c|c|}
\hline \multirow{2}{*}{$\begin{array}{l}\text { Uji biokimia } \\
\text { Biochemical test }\end{array}$} & \multicolumn{4}{|c|}{$\begin{array}{l}\text { Kode isolat bakteri nitrifikasi } \\
\text { Code of nitrifying bacteria isolates }\end{array}$} \\
\hline & NP1 & NP2 & NP3 & NP4 \\
\hline $\mathrm{NO}_{3}$ (Nitrate) & + & + & - & - \\
\hline Glukosa (Glucose) & - & + & - & - \\
\hline (Adh) & + & + & + & + \\
\hline Urea (Ure) & + & + & + & + \\
\hline Gelatin (Gel) & - & + & - & - \\
\hline (Png) & - & - & + & + \\
\hline (Glu) & - & + & + & + \\
\hline Arabinosa (Ara) & - & - & + & + \\
\hline (Mne) & - & - & + & + \\
\hline Manosa (Man) & + & + & + & + \\
\hline (Nag) & + & + & + & + \\
\hline (Gnt) & + & + & + & + \\
\hline (Cap) & - & + & + & + \\
\hline (Adi) & + & + & + & + \\
\hline (MIt) & + & + & - & - \\
\hline Asam sitrat (Cit) & + & + & - & - \\
\hline$(\mathrm{Pac})$ & + & + & + & + \\
\hline Oxidase $(0 x)$ & + & + & + & + \\
\hline Metabolisme fermentatif/oksidatif & Oksidatif & Oksidatif & Oksidatif & Oksidatif \\
\hline \multirow[t]{2}{*}{$\begin{array}{r}\text { Uji biokimia } \\
\text { Biochemical test }\end{array}$} & \multicolumn{4}{|c|}{$\begin{array}{l}\text { Kode isolat bakteri denitrifikasi } \\
\text { Code of denitrifying bacteria isolates }\end{array}$} \\
\hline & DP1 & DP2 & DP3 & DP4 \\
\hline $\mathrm{NO}_{3}$ (Nitrate) & + & + & + & + \\
\hline Glukosa (Glucose) & + & - & - & - \\
\hline (Adh) & + & + & + & + \\
\hline Urea (Ure) & + & + & + & + \\
\hline (Esc) & + & - & + & - \\
\hline Gelatin (Gel) & + & - & + & - \\
\hline (Png) & - & - & + & - \\
\hline (Glu) & - & + & + & - \\
\hline (Mne) & - & - & + & - \\
\hline (Nag) & + & - & + & + \\
\hline Maltosa (Mal) & - & - & + & + \\
\hline$(\mathrm{M} \mid \mathrm{t})$ & + & - & - & + \\
\hline Asam sitrat (Cit) & + & - & - & + \\
\hline Oxidase $(0 x)$ & + & + & + & + \\
\hline Metabolisme fermentatif/oksidatif & - & - & - & - \\
\hline $\begin{aligned} \text { Keterngan (Note): } & (+) \text { isolat dapat } m \\
& \text { untuk pertumbuh } \\
& \text { sources for growth } \\
& (-) \text {. Isolat tidak ma } \\
& \text { C untuk pertumb } \\
& \text { C sources for grow }\end{aligned}$ & $\begin{array}{l}\text { atkan miner } \\
\text { solates able } \\
\text { manfaatkan } \\
\text { (isolates no }\end{array}$ & $\begin{array}{l}\text { ngula- gula } \\
\text { use mineral } \\
\text { ral dan gula- } \\
\text { e to to use } m\end{array}$ & $\begin{array}{l}\text { ebagai sumb } \\
\text { and sugars a } \\
\text { jula sebagai } \\
\text { herals and su }\end{array}$ & $\begin{array}{l}\text { er } C \text { dan } C \\
C \text { and } C \\
\text { umber } C \text { dan } \\
\text { jars as } C \text { and }\end{array}$ \\
\hline
\end{tabular}

dan kemampuan dalam mereduksi senyawa dichlorometan (DMC) sebesar 56-85\%(Yu et al., 2013).

Berdasarkan hasil sekuensing, isolat bakteri nitrifikasi NP2 dan NP3 merupakan kelompok proteobakteri yang memiliki kekerabatan terdekat dengan jenis Pseudomonas sp. yaitu Pseudomonas aeruginosa strain PSE 12 (Gambar 2). Syahputra et al. (2011) menyebutkan bakteri Pseudomonas aeruginosa dapat digunakan sebagai agen bioremediasi yang ramah lingkungan untuk pengendalian pencemaran limbah 

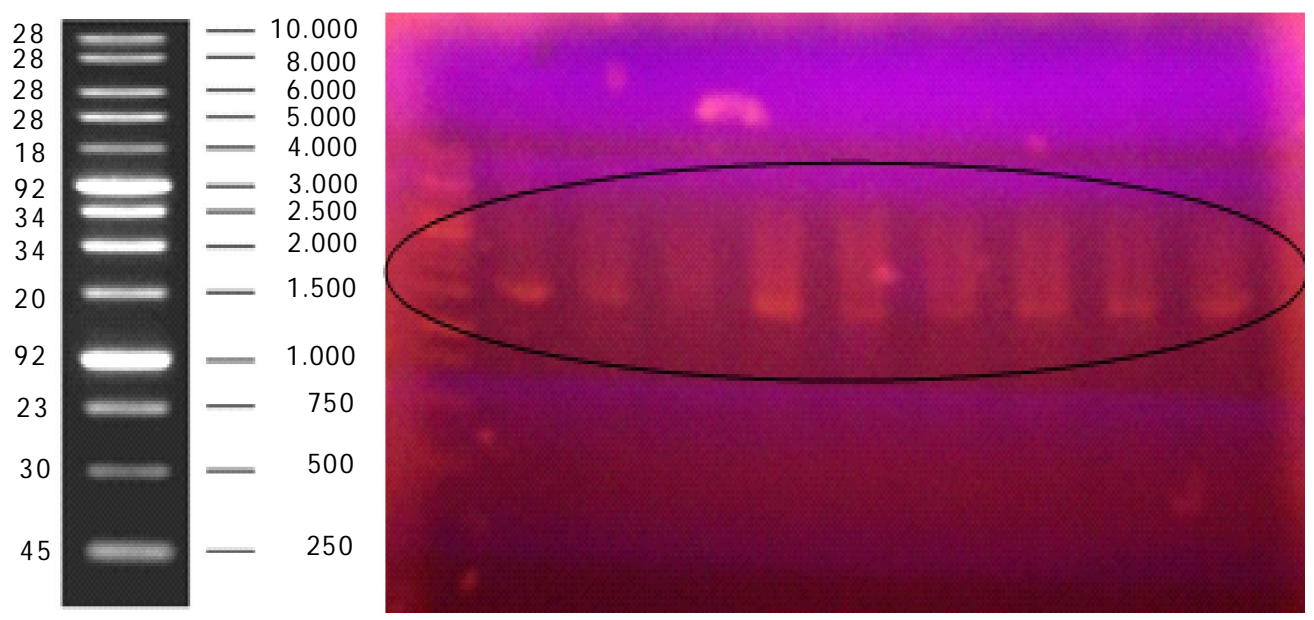

Gambar 2. Hasil PCR 16SrRNA bakteri nitrifikasi dan denitrifikasi. Pada gambar hasil PCR terdapat pita DNA pada panjang sekitar 1.300 bp ukuran tersebut mengacu pada $1 \mathrm{~Kb}$ DNA ladder.

Figure 2. Results PCR 16SrRNA from the selected nitrifying and denitrfying bacteria. The PCR results showed the lenght of DNA band is roughly $1,300 \mathrm{bp}$ the size refers to $1 \mathrm{~Kb}$ DNA ladder.

Tabel 5. Hasil BLAST N dari sekuen 16SrRNA

Table 5. BLASTN results from $16 S$ rRNA sequence

\begin{tabular}{cclcc}
\hline $\begin{array}{c}\text { Isolat } \\
\text { Isolate }\end{array}$ & $\begin{array}{c}\text { Asal isolat } \\
\text { Isolates initial }\end{array}$ & \multicolumn{1}{c}{$\begin{array}{c}\text { Homologi bakteri (Blast N) } \\
\text { Bacterial homology }\end{array}$} & $\begin{array}{c}\text { Kemiripan } \\
\text { Similarity }\end{array}$ & $\begin{array}{c}\text { Nomor aksesi } \\
\text { Accession number }\end{array}$ \\
\hline DP1 & Jambi & Achromobacter xylosoxidans strain TPL14 & 100 & EU373389.1 \\
DP2 & Jambi & Stenotrophomonas acidaminiphila strain BTY & 100 & GU265557.1 \\
DP3 & Riau & Stenotrophomonas maltophilia strain BHWSL2 & 99 & KX212258.1 \\
DP4 & Riau & Ochrobactrum intermedium strain: SQ 20 & 98 & KC195785.1 \\
NP1 & Jambi & Pandoraea pnomenusa strain 1318 & 99 & KT873852.1 \\
NP2 & Jambi & Pseudomonas aeruginosa strain PSE12 & 99 & KR815846.1 \\
NP3 & Jambi & Pseudomonas aeruginosa strain PSE12 & 99 & KR815846.1 \\
NP4 & Jambi & Burkholderia vietnamiensis strain NE 7 & 98 & EU447182.1 \\
\hline
\end{tabular}

nitrogen anorganik seperti nitrat dan nitrit. Bakteri jenis Pseudomonas sp. merupakan bakteri yang dominan berperan sebagai bakteri nitrifikasi dan paling banyak digunakan sebagai probiotik pengolahan air limbah industri perikanan, karena kemampuannya dalam mendegradasi senyawa nitrogen (Kumar et al., 2013). Pseudomonas sp. diketahui cukup toleran terhadap logam $\mathrm{Cd}$ dan resisten terhadap antibiotik (Patra et al., 2010). Bakteri ini dapat mereduksi nitrat dengan produk akhir berupa gas nitrogen (N) kerena didukung dengan kelengkapan enzim yang dimilikinya (Rusmana, 2006).

Isolat bakteri nitrifikasi NP 4 (Gambar 4) menunjukkan kekerabatan terdekat dengan jenis Burkholderia vietnamiensis strain NE 7. Bakteri jenis ini berperan penting dalam proses nitrifikasi diperairan dan merupakan bakteri yang predominan (Sombatjinda et al., 2011). Bakteri nitrifikasi heterotrof seperti Burkohlderia cepacai $\mathrm{NH}-17$ dapat mengkonversi nitrit $\left(\mathrm{NO}_{2}{ }^{-}\right)$menjadi nitrat $\left(\mathrm{NO}_{3}{ }^{-}\right)$yang selanjutnya mengubah nitrit $\left(\mathrm{NO}_{2}^{-}\right.$) menjadi $\mathrm{NO}$ dengan bantuan enzim nitrit reduktase. NO yangsudah terbentuk diubah lebih lanjut menjadi nitrat $\left(\mathrm{NO}_{3}^{-}\right)$oleh enzim NO dioksigenase dalam kondisi aerob (Matsuzaka et al., 2003).

Hasil sekuen isolat bakteri denitrifikasi DP3 menunjukkan bahwa bakteri tersebut memiliki kedekatan dengan jenis Stenotrhopomonas sp. dan pseudomonas sp. Namun, kerabat yang terdekat adalah dengan jenis Stenotrophomonas maltophilia strain BHWSL2 (Gambar 4). Genus Stenotrophomonas secara 


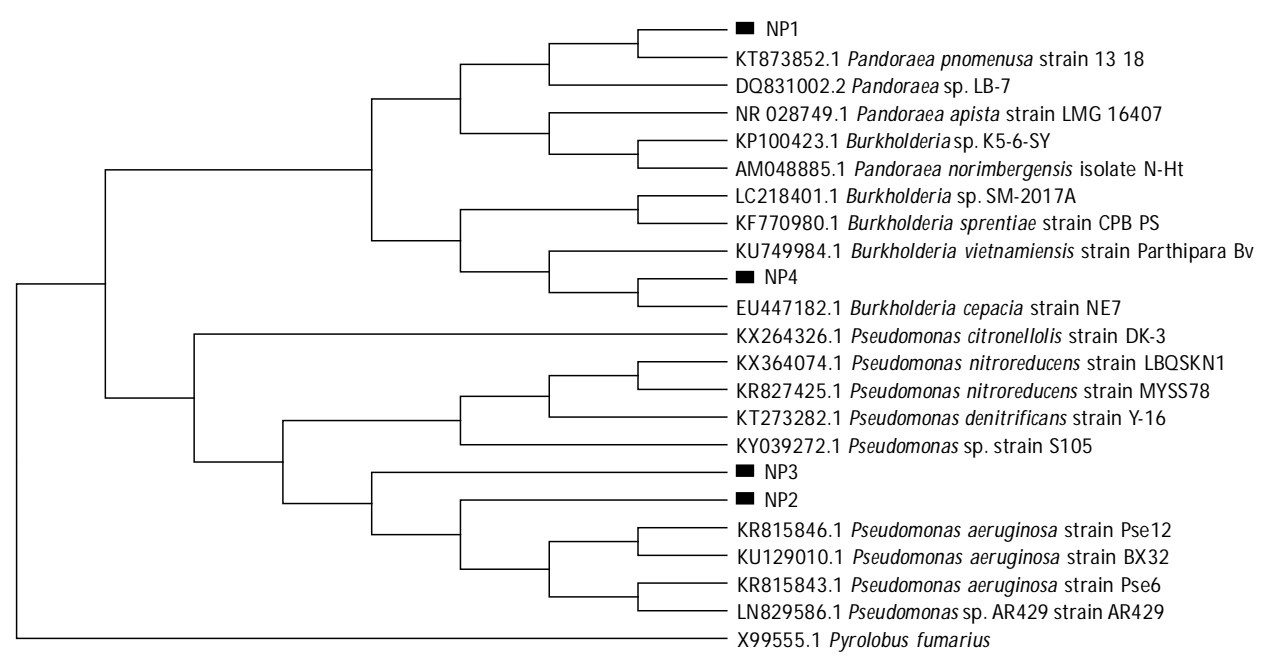

Gambar 3. Dendogram filogeni isolate bakteri nitrifikasi berdasarkan sekuen 16S-rRNA.

Figure 3. Phylogeny dendogram of nitrifying bacteria isolates based on 16S-rRNA sequence.

filogeni ditempatkan dalam gama proteobacteri yang awalnya dikenal dengan nama Stenotrophomonas maltophilia dan merupakan Xanthomonas yang termasuk ke dalam sub kelas proteobakteri (Anzai et al., 2000). Genus Stenotrophomonas merupakan genus yang dominan di alam (air, tanah, dan tumbuhan) dan memiliki distribusi yang luas serta berperan penting dalam siklus nitrogen dan sulfur (Ryan et al., 2009). Genus Stenotrophomonas baru diketahui ada 8 jenis (Yoon et al., 2006).
Hasil sekuen isolat bakteri nitrifikasi DP4 menunjukkan bahwa bakteri tersebut memiliki kekerabatan dengan genus Ochrobactrum dan yang terdekat dengan jenis Ochrobactrum intermedium strain: SQ 20. Bakteri jenis Ocrhobactrum antrhopi merupakan bakteri denitrifikasi di tanah maupun di air (Bothe et al., 2000). Bakteri 0. anthropi memiliki bentuk seperti batang atau basil, gram negatif, dan merupakan bakteri pereduksi $\mathrm{NO}_{3}$ and $\mathrm{NO}_{2}$ (Mahmood et al., 2009; Bathe et al., 2006). Bakteri jenis ini dapat hidup dalam

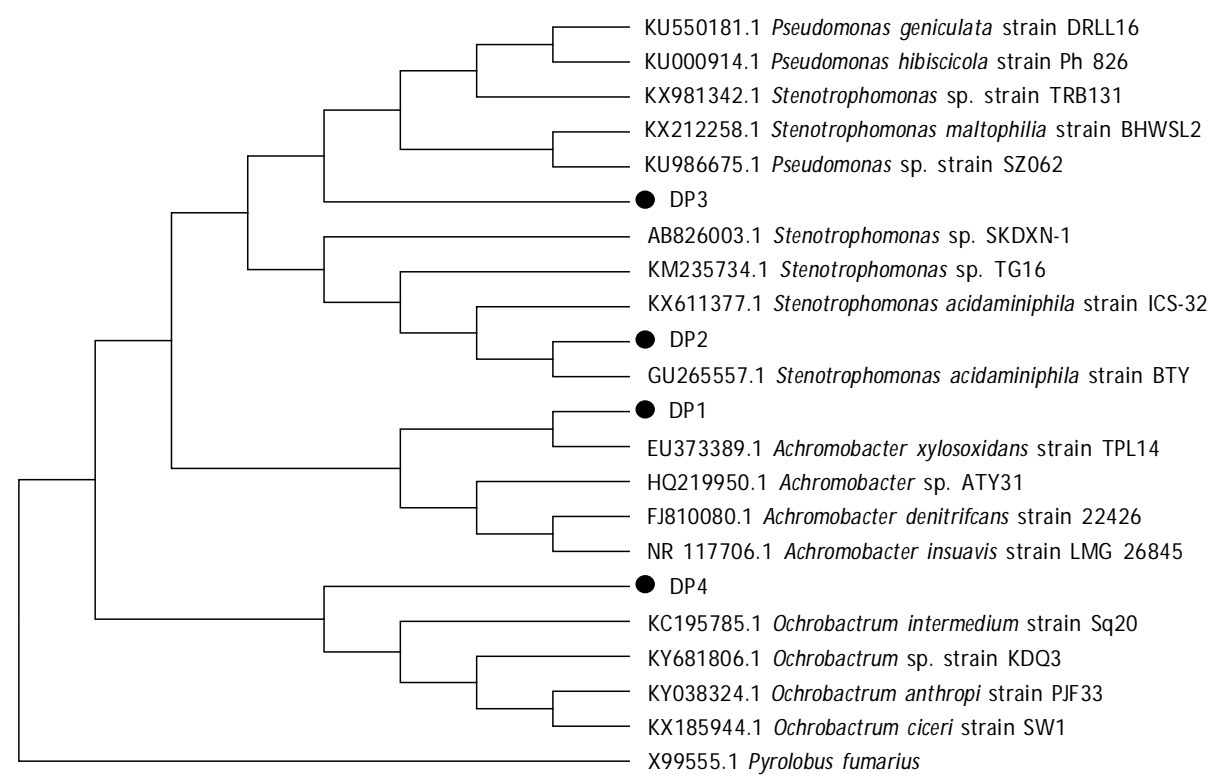

Gambar 4. Dendogram filogeni isolat bakteri denitrifikasi berdasarkan sekuen 16S-rRNA.

Figure 4. Phylogeny dendogram of nitrifying bacteria isolates based on 16S-rRNA sequence. 
lingkungan ekstrim seperti lumpur dan air yang tercemar (Mahmood et al., 2009; Kesseru et al., 2002). Onchrobactrum adalah organisme mesofilik yang dapat tumbuh pada kisaran suhu 4-40ㅇ dan kisaran $\mathrm{pH}$ 3-9, tetapi optimal pada suhu $30^{\circ} \mathrm{C}$ dan $\mathrm{pH}$ kisaran 6-7 (Lebuhn et al., 2000).

Berdasarkan hasil seleksi dan karakterisasi bakteri nitrifikasi dan denitrifikasi, diperoleh masing-masing empat isolat sebagai kandidat probiotik untuk pengendalian senyawa nitrogen pada lingkungan budidaya ikan. Hasil yang sama juga telah dilakukan oleh Saputra et al. (2011) yang mengisolasi bakteri denitrifikasi dari muara Sungai Cisadane dengan memproleh isolat Pseudomonas aeruginosai di mana dari bakteri ini dapat berperan nitrifikasi dengan uji couple process.

Berdasarkan hasil seleksi dan karakterisasi bakteri nitrifikasi dan denitrifikasi, diperoleh masing-masing empat isolat sebagai kandidat probiotik untuk pengendalian senyawa nitrogen pada lingkungan budidaya ikan.

\section{KESIMPULAN}

Berdasarkan hasil penelitian, diperoleh bakteri kandidat probiotik pengendal i senyawa nitrogen pada budidaya ikan air tawar dari kelompok nitrifikasi antara lain: Pandoraea pnomenusa strain 1318 (NP1); Pseudomonas aeruginosa strain PSE12 (NP2); Pseudomonas aeruginosa strain PSE12 (NP3); Burkholderia vietnamiensis strain NE 7 (NP4) dan kelompok denitrifikasi yaitu: Achromobacter xylosoxidans strain TPL14 (DP1); Stenotrophomonas acidaminiphila strain BTY (DP2); Stenotrophomonas maltophilia strain BHWSL2 (DP3); Ochrobactrum intermedium strain: SQ 20 (DP4).

\section{UCAPAN TERIMA KASIH}

Ucapan terima kasih kami sampaikan kepada Balai Riset Perikanan Budidaya Air Tawar dan Penyuluhan Perikanan, Bogor yang telah membiayai penelitian ini melalui APBN 2013. Ucapan terima kasih kepada Bapak Hernowo dari Dinas Perikanan dan Kelautan Provinsi Jambi dan Bapak Hasiben dari Dinas Perikanan Kabupaten Kampar Provinsi Riau.

\section{DAFTAR ACUAN}

Agustiyani, D., Kayadoe, R.M., \& Imamuddin, H. (2010). Oksidasi nitrit oleh bakteri heterotrofik pada kondisi aerobik. Jurnal Biologi Indonesia,6(2), 265-275.

Anzai, Y., Kim, H., Park, J.Y., Wakvabayashi, H., \& Oyaizu, H. (2000). Phylogenetic affiliation of the pseudomonads based on 16S rRNA sequence. Int J Syst Evol Microbiol, 50, 1563-1589.
Azhar, H.M., Ulkhaq, M.F., Suciyono, dan Prayogo. 2017. Kelimpahan dan keanekaragaman bakteri pada pembenihan ikan lele (Clarias gariepinus) dengan sistem air tertutup (close water system). Journal of Aquaculture Science,2(4), 81-89.

Badjoeri, M. \& Widiyanto, T. (2008). Penggunaan bakteri nitrifikasi untuk bioremediasi dan pengaruhnya terhadap konsentrasi amonia dan nitrit di tambak udang. Oseanologi dan Limnologi di Indonesia, 34(2), 261-278.

Bathe, S., Achouak, W., Hartmann, A., Heulin, T., Schloter, M., \& Lebuhn, M. (2006). Genetic and phenotypic microdiversity of Ochrobactrum spp. FEMS microbiology ecology, 56(2), 272-280.

Bock, E., Koops, H.P., \& Harms, H. (1989). Nitrifying bacteria. In H.G. Schlegel and B. Bowien (Editors), Autotrophic Bacteria. Science Tech Publishers, Madison, WI, 81-96.

Bothe, H., Jost, G., Schloter, M., Ward, B., \& KarlPaul, W. (2000). Molecular analysis of ammonia oxidation and denitrification in natural environments. FEMS Microbiology Reviews, 24, 673-690.

Clesceri, L.S., Greenberg, A.E., \& Eaton, A.D. (1998). Standard Methods for the Examinationof Water and Wastewater. 20th Edition.AmericanPublic Health Association, Washington, D.C., 1325 pp.

Djokosetiyanto, D., Sunarma, A., \& Widanarni. (2006). Perubahan amonia (NH-N) nitrit (NO2-N) dan nitrat (NO-N) pada media pemeliharaan ikan nila merah (Oreochromis sp.) di dalam sistem resirkulasi. Jurnal Akuakultur Indonesi, 5(1), 13-20.

United States Environmental Protection Agency (EPA). (1971). Method 352.1: Nitrogen, Nitarte (Colorimetric, Brucine) Spectrophotometer.

Fu, L.X., Yu, J.M., Cheng, Z.W., Jiang, Y.F., Chen, J.M., Gu, X.N., \& Zhu, R.Y. (2012). Characteristics of dichloromethane degradation by Pandoraea pnomenusa LX-1. Journal Enviromen Science, 32(7), 563-1571.

Hogg \& Stuart. (2013). Essential M icrobiology ( $\left.2^{\text {nd }} e d.\right)$. Wiley-Blackwell. $86 \mathrm{p}$.

Jun, X., Xiuzheng, X., \& Tongbing, Y. (2000). Phyxicochemical factors $\&$ bacteria in fish ponds. The ICLARM Quartel, 23(4), 16-20.

Kesseru, P., Kiss, I., Bihari, Z., \& Polyak, B. (2002). The effects of $\mathrm{NaCl}$ and some heavy metals on the denitrification activity of Ochrobactrum anthropi Journal of basic microbial, 42(4), 268-276.

Khasani, I. (2008). Isolasi dan skrining bakteri nitrifkasi serta aplikasinya pada biofiltrasi media pemeliharaan larva udang galah Macrobrachium rosenbergii de Man. Jurnal Riset Akuakultur, 3(3), 413-430. 
Kumar, V.J.R., Sukumaran, V., Achuthan, C., Joseph, V., Philip, R., \& Singh, S.B. (2013). Molecular characterization of the nitrifying bacterial consortia employed for the activation of bioreactors used in brackish and marine aquaculture systems. International Biodeterioration \& Biodegradation, 78, 74-81.

Lebuhn, M., Achouak, W., Schloter, M., Berge, O., Meier, H., Barakat, M., \& Heulin, T. (2000). Taxonomic characterization of Ochrobactrum sp. isolates from soil samples and wheat roots, and description of Ochrobactrum tritici sp. nov. and Ochrobactrum grignonense $\mathrm{sp}$. International Journal of Systematic and Evolutionary Microbiolog, 50(6), 2200-2207.

Long, A., Heitman, J., Tobias, C., Philips, R., \& Song, B. (2013). Anammox, denitrification, and codenitriflcation in agricultural soils. Appl. Environ. Microbiol, 79(1), 168-176.

Mahmood, Q., Hu, B., Cai, J., Zheng, P., Azim, M., Jilani, G., \& Islam, E. (2009). Isolation of Ochrobactrum sp. QZ2 from sulfide and nitrite treatment system. Journal of Hazardous Materials, 165(1), 558-565.

Marchesi, J.R., Sato, T., Andrew, T., Weightman, Martin, T.A., Fry, J.C., Hiom, S.J., \& Wade, W.G. (1998). Design and evaluation of useful bacteriumspecific PCR primers that amplify genes coding for bacterial 16S-rRNA. App Env of Microbi, 64(2), 795-799.

Matsuzaka, E., Nomura, N., \& Maseda, H. (2003). Participation of nitrite reductase in conversion of NO2- to NO3- in a heterotrophic nitrifier, Burkholderia cepacia NH-17, with denitrification activity. Microbes Environ, 18, 203-209.

Michaud, L., Blancheton, J.P., Bruni, V., \& Piedrahita, R. (2006). Effect of particulate organic carbon on heterotrophic bacterial populations and nitrification efficiency in biological filters. Aquacultural Engineering, 34, 224-233.

Novita, L., Rusmana, I., \& Widiyanto, T. (2014). Struktur pengoksidasi ammonia berdasarkan gen amoA di situ Sawangan Bojongsari, Jawa Barat. Limnotek, 21(1), 74-86

Patra, S., Das, T.K., Ghosh, S.C., Sarkar, D., \& Jana, B.B. (2010). Cadmium tolerance and antibiotic resistance of Pseudomonas sp. isolated from water, sludges, and fish raised in wastewater-fed tropical ponds. Indian Journal of Experimental Biology, 48, 383-393.

Rodina, G.A. (1972). Methode in aquatic microbiology. Dalam Rita RC. Machael S. editor: University Park Press. Baltimore USA, 461 pp.
Rusmana, I. (2003). Nitrous oxida formation in bacteria. Journal Microbiology Indonesia, 8, 63-66.

Rusmana, I. (2006). Gaseous and products of nitrat and nitrit reduction by denitrifying pseudomonads isolated from estuarine sediment. Jurnal Mikrobiologi Indonesia, 11(2), 63-66.

Ryan, R.P., Monchy, S., Cardinale, M., Taghavi, S., Crossman, L., Avison, M.B., Berg, G., Van der Lelie, D., \& Dow, J.M. (2009). The versatility and adaptation of bacteria from the genus Stenotrophomonas. Nature Reviews Mocrobiology. Macmillan Publishers Limited, 7, 514-525.

Sanders, E.R. (2012). Aseptic laboratory techniques: Plating methods. Journal of Visualized Experiments, (63), 3064.

Sogin, M.L., Morrison, H.G., Huber, J.A., Welch, D.M., Huse, S.M., Neal, P.R., Arrieta, J.M., \& Herndl, G.J. (2006). Microbial diversity in the deep sea and the underexplored"rare biosphere". Proceedings of the National Academy of Sciences of the United States of America, 103, 12115-12120.

Sombatjinda, S., Boonapathchareon, N., Ruengjitchatchawalya, M., Wantawin, C., Withyachumnarnkul, B., \& Techkarnjanaruk, S. (2011). Dynamics of microbial communities in an earthen shrimp pond during the shrimp growing period. Environment and Natural Resources Research, 1(1), 171-180.

Syahputra, K., Rusmana, I., \& Widyastuti, U. (2011). Isolasi dan karakterisasi bakteri denitrifikasi sebagai agen bioremediasi nitrogen anorganik. Jurnal Riset Akuakultur, 6(2), 197-209.

Widiyanto, T. (2006). Seleksi bakteri nitrifikasi dan denitrifikasi untuk bioremediasi di tambak udang. Disertasi. Sekolah Pasca Sarjana Institut Pertanian Bogor, $121 \mathrm{hlm}$.

Yantos. (2016). Kebijakan pemerintah Kabupaten Kampar terhadap peningkatan daya sain UMKM Desa Koto Mesjid dalam menghadapi masyarakat ekonomi ASEAN (MEA). Jurnal Risalah, 27(1), 32-45.

Yoon, J.H., Kang, S.J., Oh, H.W., \& Oh, T.K. (2006). Stenotrophomonas dokdonensissp. isolated from soil. Int. J. Syst. Evol. Microbiol, 56, 1363-1367.

Yu, J., Cai, W., Cheng, Z., \& Chen, J. (2013). Degradation of dichloromethane by an isolated strain Pandoraea pnomenusa and its performance in a biotrickling filter. Journal Enviroment Science, 13, 1-23.

Yuhana, M. (2010). Agen biokontrol dalam akuakultur: Produksi dan aplikasinya. Jurnal Akuakultur Indonesia, 9(1), 16-20. 